Phinisi Integration Review
Vol. 4, No.1, Februari 2021 Hal 144-149
Website: http://ojs.unm.ac.id/pir
p-ISSN: 2614-2325 dan e-ISSN: 2614-2317
DOI: https://doi.org/10.26858/pir.v4i1.19399

\title{
Upaya Guru IPS Dalam Meningkatkan Motivasi Belajar Siswa Pada Masa Covid 19 Di SMP
}

\author{
Andi Yosi Adiwisastra Agustang', ${ }^{1}$ Herman $^{2}$, Muh. Said ${ }^{3}$, Andi Agustang ${ }^{4}$ \\ ${ }^{1234}$ Universitas Negeri Makassar, Indonesia, \\ Email:yoshiadiwisastra@gmail.com
}

\begin{abstract}
Abstrak. Upaya guru IPS dalam meningkatkan motivasi belajar siswa pada masa Covid19 di SMP Negeri 1 Kecamatan Simbulue Kabupaten Bone dengan melakukan pendekatan personal yaitu menghubungi siswa satu persatu baik dengan berkomunikasi langsung melalui smartphone ataupun dengan chat pribadi lewat whatsapp. Selain itu, upaya yang dilakukan guru untuk siswa yang tidak memiliki smartphone adalah dengan menganjurkan siswa datang ke sekolah untuk mengambil materi dan tugas pembelajaran. Selain itu juga guru melakukan kunjungan ke rumah siswa namun tetap dengan mengikuti protokol kesehatan. Informan pada penelitian ini dengan mewawancarai 3 guru dari tiap kelas yang telah mengajarkan mata pelajaran IPS (Ilmu Pendidikan Sosial) yaitu, 1 orang dari kelas VII, 1 orang dari Kelas VIII, dan 1 orang dari Kelas IX. Hasil penelitian dalam pemberian reward selama pembelajaran online membuat siswa termotivasi untuk terus belajar meski bukan lewat tatap muka. Guru IPS juga melakukan upaya pendekatan emosional dengan orang tua siswa sebagai bentuk control terhadap perilaku dan disiplin siswa saat belajar online. Sementara upaya guru dalam meningkatkan motivasi belajar siswa yang berhubungan dengan bentuk ekspresi siswa yaitu pengerjaan tugas kelompok yang diberikan kepada siswa. Guru memberikan kebebasan kepada siswa untuk mengkomunikasikan tugas tersebut dengan cara dan aplikasi yang diinginkan oleh siswa. Hasil dari penugasan tersebut akan dipublikasikan secara umum.
\end{abstract}

Kata Kunci : Upaya Guru IPS, Motivasi Belajar, Pandemi Covid19

\begin{abstract}
Social studies teachers' efforts in increasing student motivation during the Covid-19 period at SMP Negeri 1, Simbulue District, Bone Regency by taking a personal approach, namely contacting students one by one either by communicating directly via smartphone or by private chat via WhatsApp. In addition, the efforts made by teachers for students who do not have smartphones are to encourage students to come to school to take learning materials and assignments. In addition, the teacher also made visits to students' homes but still followed health protocols. The informants in this study interviewed 3 teachers from each class who had taught Social Studies (Social Education) subjects, namely, 1 person from class VII, 1 person from Class VIII, and 1 person from Class IX. The results of research in giving rewards during online learning motivated students to continue learning even though not face to face. Social studies teachers also make an emotional approach with the parents of students as a form of control over student behavior and discipline when learning online. Meanwhile, the teacher's efforts to increase student motivation are related to the form of student expression, namely working on group assignments given to students. The teacher gives freedom to students to communicate the assignment in the way and application that the student wants. The results of the assignment will be published publicly.
\end{abstract}

Keywords: Social Studies Teacher Efforts, Learning Motivation, Covid Pandemic 
Ini adalah artikel dengan akses terbuka dibawah licenci CC BY-NC-4.0

(https://creativecommons.org/licenses/by-nc/4.0/).

\section{PENDAHULUAN}

Pendidikan merupakan aspek terpenting dalam kehidupan suatu bangsa. Pendidikan pada hakekatnya memberikan pengalamanpengalaman yang memungkinkan peserta didik mengembangkan potensinya (bakat, kemampuan, dan minatnya) secara optimal. Pendidikan adalah proses pengembangan pengetahuan dan karakter serta sikap hidup dalam diri manusia atau bangsa dalam arti utuh (Mangunwijaya, 2003:129). Utuh yang dimaksudkan oleh Mangunwijaya adalah adanya keterpaduan antara pengetahuan yang dipelajari dengan realitas kehidupan sehari-hari.

Indonesia memiliki modal yang besar dalam meningkatkan pendidikan. Modal tersebut adalah sumber daya manusia (SDM) yang sangat berharga dalam rangka melakukan percepatan dalam pendidikan. Tetapi diperlukan pengelolaan yang baik serta terstruktur agar SDM tersebut bisa sampai pada harapan yang dicita-citakan. Berkaitan dengan SDM, Isjoni, (2012) menyatakan bahwa Pendidikan identik dengan output sumber daya manusia (SDM), dan SDM yang berkualitas hanya dapat terbentuk bilamana terdapat proses pendidikan yang berkualitas. Hal ini mengisyaratkan bahwa percepatan pendidikan merupakan point penting bagi pembangunan negara. Artinya pembangunan bangsa dan Negara ini salah satunya ditentukan oleh ketercapaian dari pembangunan pendidikan.

Kondisi saat ini diberbagai lini kehidupan sedang mengalami goncangan yang diakibatkan oleh pandemi Covid19. Kondisi ini tak hanya dirasakan oleh Indonesia semata tetapi juga seluruh negara di dunia ini. Kondisi tersebut juga menyisir dunia pendidikan yang akhirnya terjadi kekacauan dan kekhawatiran akan kondisi pendidik dan peserta didik. Para pendidik di Indonesia tak pernah sebelumnya dibekali pengetahuan atau metodologis pengajaran ketika situasi seperti ini terjadi.

Langkah tercepat yang dilakukan pemerintah untuk menanggulangi efek Covid19 ini adalah dengan melakukan pembatasan sosial yang juga diterapkan pada dunia pendidikan. Dalam usaha pembatasan sosial ini pemerintah Indonesia telah membatas kegiatan diluar rumah seperti kegiatan pendidikan yang telah dilakukan secara Daring melalui pembelajaran online.
(Mona, N. 2020). Walaupun pembelajaran ini menggunakan kecanggihan serta kemajuan teknologi, namun pembelajaran online ini terbilang sebagai proses pembelajaran baru sehingga baik tenaga pendidik maupun peserta didik memerlukan waktu untuk beradaptasi.

Pembelajaran online yang menggunakan jaringan internet dan perangkat lainnya menjadi langkah taktis yang diambil agar proses belajar dan mengajar tetap berlangsung. Pembelajaran online ini bisa dilakukan dengan menggunakan media, baik media cetak (modul) maupun non cetak (audio/video), komputer/internet, siaran radio dan televisi. (Patria, L., \& Yulianto, K. 2011).

Dalam dunia pendidikan, seorang guru mempunyai peran yang sangat besar bagi seorang anak dalam belajar. Berdasarkan hal tersebut, diketahui bahwa guru merupakan salah satu faktor yang berpengaruh terhadap motivasi dan prestasi belajar. Guru memiliki cara dan pola tersendiri dalam mengasuh, membimbing dan meningkatkan motivasi belajar anak. Cara dan pola tersebut tentu akan berbeda antara satu guru dengan guru yang lainnya. Pola asuh guru merupakan gambaran tentang sikap dan perilaku guru dan anak dalam berinteraksi, berkomunikasi selama mengadakan kegiatan belajar mengajar.

Hamzah B. Uno (2007) mendefinisikan motivasi adalah kekuatan, baik dari dalam maupun dari luar yang mendorong seseorang untuk mencapai tujuan tertentu yang sudah ditetapkan sebelumnya. Hal senada disampaikan oleh Mc. Donald (Sardiman A. M., 2010), tentang motivasi. Motivasi adalah perubahan energi dalam diri seseorang yang ditandai dengan munculnya feeling dan didahului dengan tanggapan terhadap adanya tujuan. Kedua gambaran akan motivasi tersebut memperlihatkan bahwa motivasi dibangun karena adanya kemauan dari seseorang yang berupa dorongan dari dalam diri dan ditunjang dari faktor luar sehingga motivasi tersebut terarah sampai pada tujuan. Dalam hal ini intensitas berkomunikasi dan bertemu menjadi kunci dalam melahirkan motivasi yang besar.

Motivasi adalah hasrat, dorongan dan kebutuhan seseorang untuk dapat melakukan aktivitas tertentu. Sehingga motivasi diartikan sebagai kekuatan yang mendorong tindakan 
Agustang, Heman, Said, Agustang. Upaya Guru IPS Dalam Meningkatkan Motivasi Belajar...

menuju suatu tujuan (Cleopatra, M. 2015). Tetapi pada setiap kondisi pandemi ini yang merupakan kondisi yang baru dan tak terduga, seorang guru dituntut bisa menciptakan inovasi yang akhirnya bisa selalu membuat peserta didik berada dalam proses pembelajaran yang efektif. Proses pembelajaran yang dirasa efektif dalam kondisi masih mewabahnya virus Covid19 yaitu pembelajaran online rupanya tidak sesuai harapan. Metode tersebut tak membuat para peserta didik menjadi semakin termotivasi untuk belajar. Peserta didik mengalami keterbatasan untuk menyampaikan aspirasi serta pemikiranpemikirannya. Ini mengakibatkan proses pembelajaran menjadi jenuh dan tidak terbangun kondisi sosiologis serta psikologis antar peserta didik dan pendidik. Kejenuhan tersebut mengakibatkan prestasi belajar siswa menjadi menurun.

Kondisi ini ditemukan oleh peneliti saat melakukan penelitian awal di SMP Negeri 1 Kecamatan Sibulue Kabupaten Bone. Melalui wawancara awal yang dilakukan pada salah satu guru IPS (Ilmu Pendidikan Sosial) menyatakan bahwa "terlihat siswa sepertinya hanya mengerjakan tugas apa adanya saja. Siswa juga terkadang hanya melakukan absen online dan ketika diberikan tugas, hanya sedikit yang meresponnya".

Lebih lanjut lagi guru tersebut menyatakan bahwa "sepertinya siswa kehilangan semangat belajar dan lebih menikmati kondisi ini seperti libur sekolah yang kebanyakan. Sehingga proses pembelajaran tidak diikuti dengan serius. Guru juga mengalami kendala dalam memotivasi siswa karena keterbatasan ruang serta waktu. Ditambah lagi kebanyakan siswa dan orang tua mengeluh akan paket data internet yang digunakan sangatlah banyak dan mahal".

Informasi awal tersebut menunjukkan bahwa motivasi siswa dalam proses belajar mengajar melalui media online dimasa covid-19 ini mengalami penurunan yang berefek pada kemajuan pembelajaran siswa. Pembelajaran online menciptakan batasan sosial dan psikologis antara guru dan peserta didik sehingga yang terjadi tak lebih hanya penuntasan kewajiban baik sebagai guru maupun sebagai peserta didik.

Motivasi belajar menjadi menurun karena tidak adanya controling dari guru akan apa aktivitas peserta didik disaat proses pembelajaran online. Peserta didik yang mengalami gangguan pada motivasi belajar maka dengan sendirinya akan menciptakan prestasi belajar yang diluar dari harapan. Hal ini menuntut guru untuk bisa menciptakan solusi agar siswa tidak kehilangan motivasi belajarnya.

\section{METODE}

Penelitian ini merupakan jenis penelitian kualitatif yaitu suatu proses penelitian dan pemahaman yang berdasarkan pada metodologi yang menyelidiki suatu fenomena sosial dan masalah manusia. Dimana Penelitian ini dilaksanakan di SMP Negeri 1 Kecamatan Sibulue Kabupaten Bone. Kedudukan metode penelitian berisikan argumentasi tentang pemilihan pendekatan/ metode berdasarkan : sifat variabel yang diteliti dan jenis informasi yang dibutuhkan. Tahapan yang harus dilalui dalam metode penelitian menurut Agustang (2015) yaitu, Identifikasi satuan analisis : orang (Kelompok/ individu) atau gejala (Bahasa, perkawinan, kota, mitos dan lain-lain), Identifikasi sasaran penelitian (populasi dan lokasi), Identifikasi dan sumber- sumber informasi (orang, dokumen, lembaga); cara mendapatkan sumber informasi (akses ke orang/ dokumen/lembaga) dan cara mendapatkan informasi (observasi, wawancara, dan lainlain),Menguraikan cara analisis (dengan statistik dan atau interpretasi kualitatif), dan Lampirkan instrumen pengumpulan data Quesioner/angket, pedoman wawancara/ pengamatan,dan lainlain).

Pemilihan informan dalam penelitian ini menggunakan cara purposive sampling yaitu teknik pengambilan sumber data dengan pertimbangan tertentu yakni sumber data dianggap paling tahu tentang apa yang diharapkan (Sugiyono. 2008). Purposive sampling dilakukan dengan cara mengambil subjek bukan didasarkan atas strata, random atau daerah tetapi didasarkan atas adanya tujuan tertentu (Arikunto. 2010). Adapun informan yang dipilih pada penelitian ini yaitu yang sesuai dengan ciri-ciri atau berdasarkan tingkat informasi yang dibutuhkan, bersedia diwawancarai, dapat menjadi sumber data yang baik dan dapat dipercaya. Informan utama adalah guru SMP Negeri 1 Kecamatan Sibulue Kabupaten Bone sebanyak 3 orang. Masingmasing guru tersebut dari Kelas VII, Kelas VIII, Kelas IX yang telah mengajarkan mata pelajaran IPS (Ilmu Pendidikan Sosial). 


\section{HASIL DAN PEMBAHASAN}

Pandemi Covid19 telah membuat kepanikan dan membuat hampir seluruh proses kehidupan berubah baik secara proses maupun hasil. Langkah cepat yang ditempuh pemerintah adalah pembatasan aktivitas social (PSBB). Dalam usaha pembatasan sosial ini pemerintah Indonesia telah membatas kegiatan diluar rumah seperti kegiatan pendidikan yang telah dilakukan secara daring melalui pembelajaran online (Mona, N. 2020). Hal ini dipertegas oleh pemerintah melalui Menteri Pendidikan yang telah mengeluarkan keputusan mengenai pembelajaran yang dilaksanakan dalam rumah (School From Home). Langkah ini ditempuh demi melindungi peserta didik dan tenaga kependidikan dari penyebaran Covid19. Langkah ini pula membuat guru atau tenaga pendidik harus merubah metode pembelajaran yang disesuaikan dengan kondisi saat ini.

Berdasarkan keterangan dari guru IPS Kelas VIII, kebiasaan para siswa atau peserta didik dalam proses belajar mengajar yang dilakukan dari senin hingga sabtu dan dilaksanakan dengan tatap muka langsung, dikarenakan adanya kejadian ini maka pembelajaran dilakukan dengan pembelajaran online. Pembelajaran online yaitu pembelajaran dilakukan dengan menggunakan media, baik media cetak (modul) maupun non cetak (audio/video), komputer/internet, siaran radio dan televise (Patria, L., \& Yulianto, K.2011). Selain pembelajaran sistem online, juga sekolah dalam hal ini guru mata pelajaran memberikan materi pelajaran atau penugasan kepada peserta didik yang telah diperbanyak oleh pihak sekolah. Siswa dapat datang ke sekolah untuk mengambil materi-materi tersebut serta akan mendapatkan penjelasan dari guru mata pelajaran agar tidak terjadi kesalahpahaman dalam pengerjaan tugas. Hal ini dilakukan tentunya dengan tetap mengedepankan protokol kesehatan. Langkah ini ditempuh karena tidak semua siswa bisa mengikuti pembelajaran online dikarenakan keterbatasan fasilitas baik smartphone maupun paket data.

Kondisi yang ideal pada saat pandemi covid19 yang berhubungan dengan pembelajaran adalah saat siswa memiliki perangkat pembelajaran yang memadai sehingga tidak terjadi kendala dalam proses pembelajaran. Namun faktanya tidak semua siswa memiliki perangkat tersebut. Maka kreativitas seorang pendidik atau guru dituntut lebih dari sebelumnya. Kreativitas guru merupakan salah satu yang dapat mendorong motivasi belajar siswa, sebab guru yang kreatif dapat untuk mengembangkan kemampuannya, menciptakan ide-ide baru dalam menjalankan perannya sebagai pengajar (Oktiani, 2017).

Pemaparan di atas memberikan gambaran sekaligus informasi bagaimana modifikasi proses pembelajaran sekarang pada SMP Negeri 1 Kecamatan Simbulue Kabupaten Bone. Modifikasi atau perubahan tersebut pastinya menciptakan kondisi yang juga tidak biasa untuk peserta didik. Hal itu juga akan mempengaruhi motivasi belajar siswa. Sementara, motivasi belajar adalah hal yang penting bagi siswa dalam proses pembelajaran. Menyadari akan pentingnya motivasi belajar siswa dan dihadapkan dengan kenyataan yaitu pembelajaran jarak jauh di tengah pandemi Covid19, maka guru harus mengambil langkah yang strategis sebagai usaha dan upaya untuk tetap menjaga dan menumbuhkan motivasi belajar siswa. Langkah tersebut haruslah dipastikan efektif dan tepat sasaran sehingga penghambat dari motivasi belajar siswa tersebut dapat diminimalisir.

\section{Upaya Guru IPS Dalam Meningkatkan Motivasi Belajar Siswa Pada Masa Covid - 19 Di SMP Negeri 1 Kecamatan Simbulue Kabupaten Bone}

Berdasarkan hasil wawancara yang telah dilakukan peneliti dengan guru IPS kelas VII, ditemukan upaya meningkatkan motivasi belajar siswa adalah dengan cara menghubungi satu persatu peserta didik dan mengapresiasi setiap penugasan yang telah dikerjakan oleh siswa. Penugasan-penugasan yang dikerjakan oleh siswa juga dipublikasikan dan dilaporkan langsung kepada kepala sekolah sebagai bentuk pertanggungjawaban dari guru bersangkutan. Selain itu, bagi siswa yang terkendala dalam pembelajaran online, guru mata pelajaran IPS biasanya melakukan kunjungan ke rumah siswa bersangkutan. Kunjungan tersebut dilakukan untuk memudahkan proses pembelajaran selama pandemi Covid19.

Upaya yang berbeda dalam meningkatkan motivasi belajar siswa dilakukan oleh guru IPS kelas IX. Berdasarkan wawancara yang dilakukan, upaya yang dilakukan adalah dengan membuat tugas yang diberikan menjadi seperti lomba. Sehingga dari hasil pemeriksaan tugas-tugas yang diberikan selama sebulan, akan diakumulasi nilainya dan tiga orang yang 
Agustang, Heman, Said, Agustang. Upaya Guru IPS Dalam Meningkatkan Motivasi Belajar...

paling tinggi nilainya akan diberikan penghargaan berupa paket data.

Berdasarkan pernyataan guru IPS kelas IX tersebut tergambar bahwa penghargaan atau reward bisa menjadi salah satu solusi untuk meningkatkan motivasi belajar siswa. Menurut Hapsari \& Christiana (2013) pemberian penghargaan atau reward dapat menjadi suatu rangsangan untuk meningkatkan motivasi belajar peserta didik, sehingga anak merasa bahwa yang telah dilakukannya tidak sia-sia karena telah dihargai.

Sementara itu, berdasarkan hasil wawancara dengan guru IPS kelas VIII menyatakan bahwa, proses pembelajaran selama pandemi covid19 ini memang dilakukan secara online dan terkadang juga siswa datang ke sekolah untuk menjemput materi atau tugastugas yang telah disiapkan. Dalam seminggu, siswa diwajibkan datang mengambil materi atau tugas di sekolah yang dimana saat mata pelajaran itu berlangsung maka absensi dilakukan lewat grup Whatsapp yang disertai dengan foto-foto belajar. Selain itu, guru IPS kelas VIII juga melakukan komunikasi dengan orang tua siswa untuk mengetahui respon dari siswa dengan metode pembelajaran online. Hal ini dilakukan agar bisa mengukur efektivitas dan efesiensi dari pembelajaran daring. Dari informasi orang tua juga dapat dijadikan solusi dari kendala-kendala pembelajaran online. Hal ini juga dilakukan untuk tetap menjaga hubungan emosional antara guru, siswa dan orang tua.

Pernyataan guru IPS kelas VIII di atas menunjukkan bahwa proses pembelajaran online tidaklah boleh membatasi hubungan emosional antara guru, siswa dan orang tua sehingga komunikasi harus tetap dijaga. Ini juga berfungsi sebagai controling berupa laporan kondisi siswa selama belajar dirumah secara online.

Untuk penugasan yang berupa video, guru VII menerapkan kerja kelompok online dan konten dari video tersebut adalah kejadiankejadian atau fakta-fakta terdekat dalam lingkungan sosial. Guru tersebut memberikan kebebasan kepada siswa untuk melalukan rapat online dengan teman-teman kelompoknya yang dibuktikan dengan hasil screenshot saat para siswa mengadakan rapat. Video-video yang telah dibuat siswa akan dinonton secara online dan publish untuk umum.

\section{SIMPULAN DAN SARAN}

Berdasarkan hasil penelitian ini dapat disimpulkan bahwa upaya guru IPS dalam meningkatkan motivasi belajar siswa pada masa Covid-19 di SMP Negeri 1 Kecamatan Simbulue Kabupaten Bone dengan melakukan pendekatan personal yaitu menghubungi siswa satu persatu baik dengan berkomunikasi langsung melalui smartphone ataupun dengan chat pribadi lewat whatsapp. Selain itu, upaya yang dilakukan guru untuk siswa yang tidak memiliki smartphone adalah dengan menganjurkan siswa datang ke sekolah untuk mengambil materi dan tugas pembelajaran. Selain itu juga guru melakukan kunjungan ke rumah siswa namun tetap dengan mengikuti protokol kesehatan. Upaya yang lain yaitu adalah dengan memberikan penghargaan atau reward kepada siswa yang mengerjakan tugas dengan nilai yang tinggi. Pemberian reward tersebut membuat siswa termotivasi untuk terus belajar meski bukan lewat tatap muka. Guru IPS juga melakukan upaya pendekatan emosional dengan orang tua siswa sebagai bentuk control terhadap perilaku dan disiplin siswa saat belajar online. Sementara upaya guru dalam meningkatkan motivasi belajar siswa yang berhubungan dengan bentuk ekspresi siswa yaitu pengerjaan tugas kelompok yang diberikan kepada siswa. Guru memberikan kebebasan kepada siswa untuk mengkomunikasikan tugas tersebut dengan cara dan aplikasi yang diinginkan oleh siswa. Hasil dari penugasan tersebut akan dipublikasikan secara umum.

\section{DAFTAR RUJUKAN}

Andi Agustang. (2015). Dasar-Dasar Filsafat Penelitian Untuk Pengembangan Ilmu.

Aulina, C. N. (2018). Penerapan Metode Whole Brain Teaching dalam Meningkatkan

Motivasi Belajar Anak Usia Dini. Jurnal Obsesi : Jurnal Pendidikan Anak Usia Dini,

2(1), 1. https://doi.org/10.31004/obsesi.v2i1.1

Cleopatra, M. (2015). Pengaruh gaya hidup dan motivasi belajar terhadap

prestasi belajar matematika. Formatif: Jurnal Ilmiah Pendidikan MIPA,

Fathurrahman. (2020). Penggunaan Metode Pembelajaran Role Playing Dalam

Menumbuhkan Motivasi Belajar Pada Pembelajaran Sejarah [Preprint].

https://doi.org/10.35542/osf.io/stnwa 
Hamzah B. Uno. (2007). Teori Motivasi dan Pengukurannya. Jakarta: Bumi

Aksara

Hapsari, R. P., \& Christiana, E. (2013). Studi Tentang Pelaksanaan Pemberian

Reward Dalam Meningkatkan Motivasi Belajar Kelompok-A Di TK Islam Al-Azhar 35 Surabaya. Jurnal Mahasiswa Bimbingan Konseling UNESA, 4(1), 274-

$284 . \quad$ Diambil dari http://jurnalmahasiswa.unesa.ac.id/ind ex.php/jurnal-bkunesa/article/view/6591

Isjoni. (2012). Memajukan Bangsa Dengan Pendidikan. Yogyakarta: Pustaka Pelajar

Mona, N. (2020). Konsep Isolasi Dalam Jaringan Sosial Untuk Meminimalisasi

Efek Contagious (Kasus Penyebaran Virus Corona Di Indonesia). Jurnal

Sosial Humaniora Terapan Universitas Indonesia,

Oktiani, I. (2017). Kreativitas Guru dalam Meningkatkan Motivasi Belajar

Peserta Didik. Jurnal Kependidikan, 5(2), 216232.

https://doi.org/10.24090/jk.v5i2.1939

Patria, L., \& Yulianto, K. (2011). Pemanfaatan Facebook untuk Menunjang

Kegiatan Belajar Mengajar Online Secara Mandiri. Repository UT,

Sardiman. A. M. (2007). Interaksi Dan Motivasi Belajar Mengajar. Jakarta: PT.

Raja Grafindo Persada.

Siregar, H. I. (2015). Peningkatkan Motivasi Belajar Siswa Dalam Pembelajaran

Microsoft Excel Dengan Menggunakan Metode Tutor Sebaya Di Kelas VIII-

D SMP Negeri 1 Batangkuis. SCHOOL EDUCATION JOURNAL PGSD FIP UNIMED, 4(1), 127-140. https://doi.org/10.24114/sejpgsd.v4i1. 2982

Suryani, M. (2015). Meningkatkan Motivasi Belajar Pembelajaran Untuk Siswa

Kelas V SD Negeri 04 Pasar Pandan Air (PPA) Mati Solok Melalui Metode

Inquiry. Inovasi Pembelajaran Berbasis Riset di Sekolah Dasar, $1,1$.

Diambil dari

http://ejournal.unp.ac.id/index.php/prosidingpgs $\mathrm{d} /$ article/view/4872 